\title{
口腔内規格写真撮影のための簡便な装置についで
}

\author{
泉澤勝憲福田光男野口俊英仲島知美 \\ 大出てい子北村滋木下四郎 \\ 東京医科歯科大学歯学部第 2 歯科保存学教室 \\ （主任 : 木下四郎教授） \\ （昭和 56 年 9 月 20 日受付）
}

\section{A Simple Device for Taking Standardized Intra-Oral Photographs}

\author{
Katsunori IZUMIZAWA, Mitsuo FUKUDA, Toshihide NOGUCHI, \\ Tomomi NAKAJIMA, Teiko OIDE, Shigeru KITAMURA \\ and Shiro KINOSHITA \\ Department of Periodontology, School of Dentistry \\ Tokyo Medical and Dental University \\ (Chief : Prof. Shiro KINOSHITA)
}

Standardized intra-oral photographic device is very useful for longitudinally evaluating plaque accumulation or degree of inflammation. Many devices are developed for this purpose, but most of them seem to have some short-comings for simple clinical use. A simple device for taking intra-oral standardized photographs with high reproducibility was developed. The device is composed of a camera (Medical Nikkor, Auto $1: 5.6, \mathrm{f}=200 \mathrm{~mm}$ ), a circular attachment to the lens of the camera made of acrylic resin, and a distance-adjustable tripod connected to the attachment. Using this device, intra-oral photographs of labial aspects of upper central incisors were taken. The subjects were ten dental students and two faculties. Two examiners (K.I., M.F.) took photographs once a day for one subject. Reproducibility of this device was studied calculating repeatedly the area of the same tooth surface on slides which were projected on a section paper ( $5 \mathrm{~mm}$ square). The distance between two special points on a tooth was also calculated for studying the reproducibilty of the device. The average coefficient of variation for the area of a tooth was $3.2 \%$, and $1.6 \%$ in the case of the distance between two special points of a tooth. From these results, this device seemed to be a very simple method for taking standardized intra-oral photographs with high reproducibility.

ることが多い。

写真に規格性を与えるためには，被写体とカメラとの 幾何学的な関係を一定とすればよいということから, 多 くの装置, 方法が発表されている1 5)が，いずれも，装 置や操作が煩雑で, 日常臨床に実用されにくいうらみが ある。

本研究は, 簡単な操作で, 高い精度の規格写真を撮影
本論文の要旨は, 第 24 回春季日本歯周病学会総会 (1981) に て発表した。
口腔内写真は，口腔内を観察するための資料として， 日常頻繁に用いられている。とくにプラーク沈着を経時 的に観察する場合であるとか, 患者の症状の時間的推移 や治療効果の判定などのために同一部位をくりかえして 記録する場合などには，その規格性，再現性が問題とな 

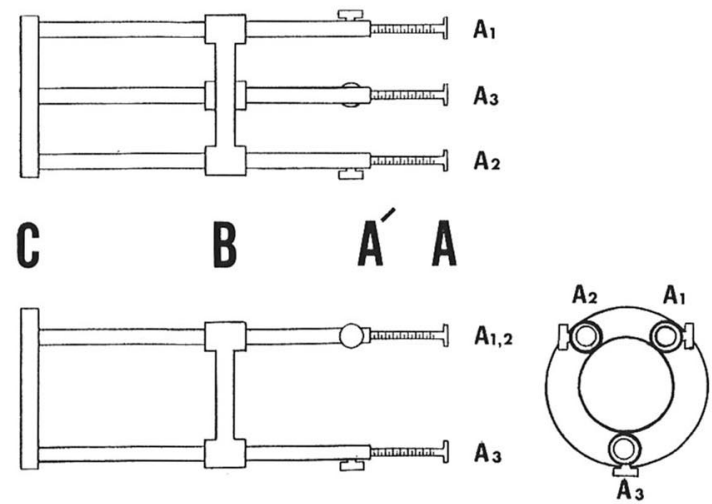

図 1 規格装置の構造

するための装置を開発することを目的としておこなっ た。

\section{装置の構造と使用法}

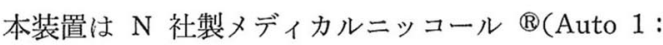
$5.6, \mathrm{f}=200 \mathrm{~mm}$ ) を用い, 1 倍にて, 上鿓前歯部を撮影 するために考案された。本装置は, 図 1 に示すように， カメラのレンズにぴったりと適合するアクリリックレジ ン製の取りつけ部分 C, 被検者の顔面に 3 点で接触する 脚部 $A_{1}, A_{2}, A_{3}$ よりなり, それを $B$ 部分で補強した形 をとっている。 $\mathrm{A}_{1}, \mathrm{~A}_{2}, \mathrm{~A}_{3}$ は，それぞれ， $\mathrm{A}_{1}^{\prime}, \mathrm{A}_{2}^{\prime}, \mathrm{A}_{3}^{\prime}$ よ り自由にスライドするようになっており，この部分を調 整することによって，被検者の顔面形態に対応すること ができる。Cは，メディカルニッコールの外径に合わせ て, 内径 $77 \mathrm{~mm}$ の円形とし, $\mathrm{C} \sim \mathrm{A}^{\prime}$ 間は, 撮影倍率 1 倍の焦点距離およぴ $\mathrm{AA}^{\prime}$ 間の調整能力を考虑して, 215 $\mathrm{mm}$ とした。 $\mathrm{A}_{1}, \mathrm{~A}_{2}, \mathrm{~A}_{3}$ は, $\mathrm{A}_{3}$ を頂点とする二等辺三角 形を形ゔくるうになっており， $A_{1} A_{2}$ 間は $70 \mathrm{~mm}, A_{1}$ $\mathrm{A}_{3}$ および $\mathrm{A}_{2} \mathrm{~A}_{3}$ 閒は $80 \mathrm{~mm}$ とした。 $\mathrm{AA}^{\prime}$ 間は, 最大 $53 \mathrm{~mm}$, 自由にスライドできるようにした。

使用法は，図 2 に示すように，まず，C部分をカメラ にしっかりと固定し, $\mathrm{AA}^{\prime}$ 間を適当に伸ばして, 被検者 に対する。被検者には, 適当なバイトブロックを咬合さ せるか, あるいは, 中心咬合位でしっかりと咬合するよ うに命じ，上下顎の顎閒関係を安定させる。 $\mathrm{A}_{1}, \mathrm{~A}_{2}$ は， 顔面の鼻部両側にあたるようにし， $\mathrm{A}_{3}$ は，おとがいと下 口唇の閒にあたるようにする。検者は, カメラのファイ ンダーをのぞき，図 3 に示すように，フォーカシングス クリーン上のスプリットマイクロプリズムの外側の円弧 が，1|1の切縁を結んだ線に中央部分で接するようにし

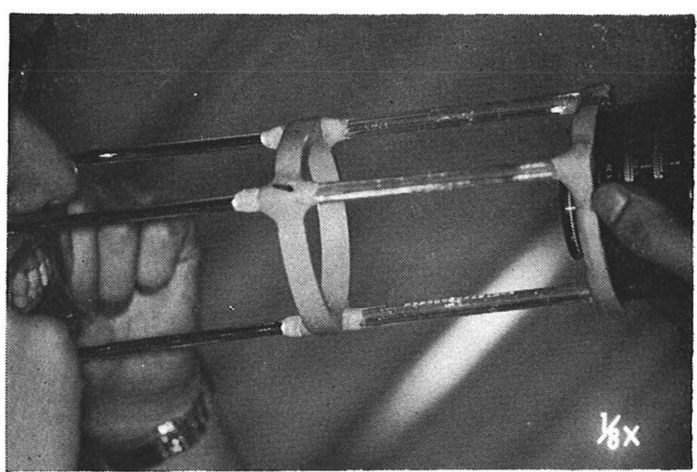

図 2 規格装置の使用法

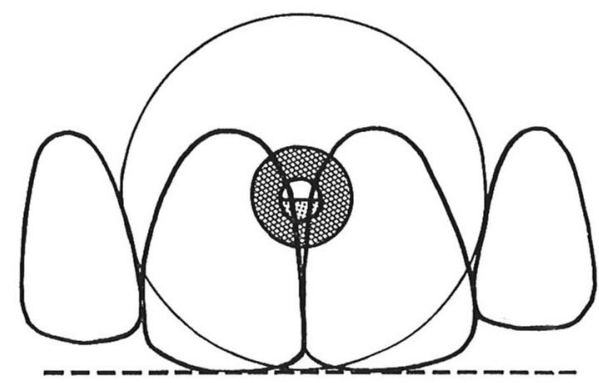

図 3 視野の決定法: 図では, フォーカシン グスクリーン上のスプリットマイクロ プリズムの外側の円弧が， $1 \mid 1$ の切縁 を結んだ線に中央部分で接するように して，視野中央部の固定を図っている。

てピントを合わせる。そのときの各々の $\mathrm{AA}^{\prime}$ 閒の目盛 を読みとり，記録して执いて，次回の撮影にそなえる。 次回撮影時には, この距離を先に調整してから, ファイ ンダーをのぞいて前述した操作をおこなえば，自動的に 焦点が合い，規格写真が撮影される。

\section{本装置の精度}

本装置の精度を検討するために，以下の実験をおこな った。

\section{材料と方法}

被検者は, 東京医科歯科大学歯学部の職員, 女性 1 名 (29 歳), 男性 1 名 (36 歳), 抒よび, 男子学生 10 名 (23 歳〜26 歳) とした。被検者は, 上顎前歯部に, う蝕, 歯 周疾患等のない健康者であった。

写真撮影は，1日 1 回とし，日を替えて，女性職員で 
は 8 回, 男性職員では 7 回, 男子学生では 5 回, $\mathrm{AA}^{\prime}$ 間 を各人について計測された值に，そのつど調整して，く りかえしおこなった。職員 2 名については, トシコン® のへビータイプにより作製したバイトブロックを左右臼 歯部で咬ませ, 学生 10 名については, 中心咬合位でし っかりと咬合させて，上下顎の顎間関係を安定させた。 撮影は経験のある 2 名がおここなっ。フィルムは F 社製

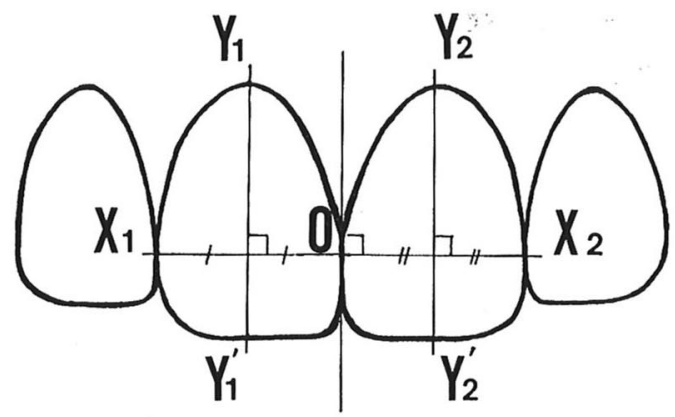

図 4 測定点の作図法
フジクローム RD 100®を用いた。

評価法としては，できあがったスライドを $5 \mathrm{~mm}$ 目の 方眼紙に 10 倍で拡大投影し， $1 \mid 1$ をトレースした。そ して，(1) その面積を， $5 \mathrm{~mm}$ 平方のます目を数えること で求め, その数值の各スライドごとのばらつきを調心 た。この場合，ます目の $1 / 2$ を占めていない部分は，ま す目の数に入れなかった。つぎに, (2) 図 4 に示すよう に，1|1の接触点 $\mathrm{O}$ にひいた接線に直交する直線が 1 お よび 1 の遠心と交わる点 $\mathrm{X}_{1}, \mathrm{X}_{2}$ を設定し, $\mathrm{OX}_{1}, \mathrm{OX}_{2}$ の 距離を測定した。また, $\mathrm{OX}_{1}, \mathrm{OX}_{2}$ の垂直 2 等分線が, 歯頸線および切縁と交わる点 $\mathrm{Y}_{1}, \mathrm{Y}_{1}^{\prime}, \mathrm{Y}_{2}, \mathrm{Y}_{2}^{\prime}$ を設定し, $\mathrm{Y}_{1} \mathrm{Y}_{1}^{\prime}, \mathrm{Y}_{2} \mathrm{Y}_{2}^{\prime}$ の距離を測定し, これらの距離 $\mathrm{OX}_{1}, \mathrm{OX}_{2}$, $\mathrm{Y}_{1} \mathrm{Y}_{1}^{\prime}, \mathrm{Y}_{2} \mathrm{Y}_{2}^{\prime}$ の変動を調べた。

\section{結果}

本装置を使用して撮影された規格写真の 1 例を図 5 (a〜d) に示す。これは表 $1 ， 2$ に拉ける被検者 2 にあ

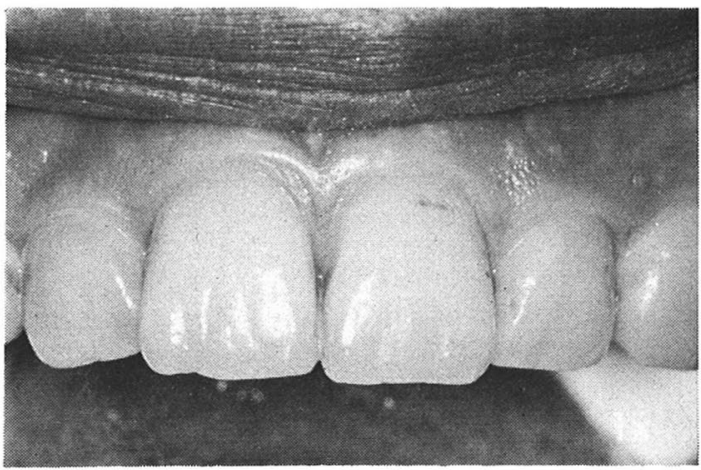

a

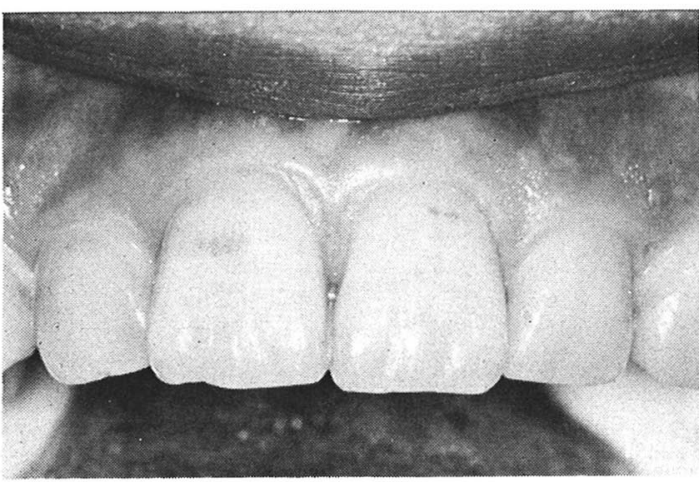

$\mathrm{C}$

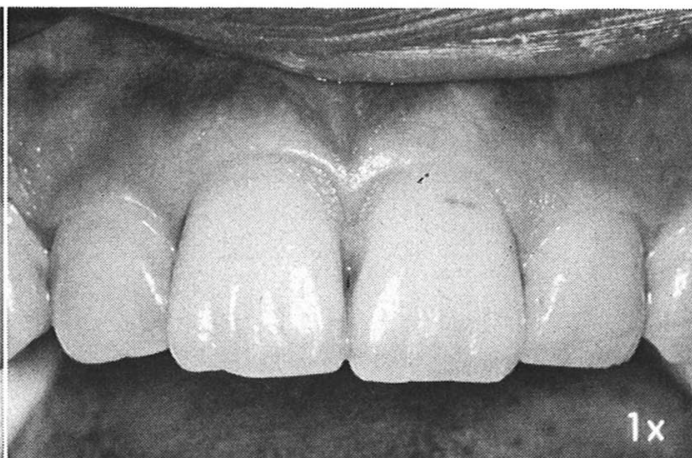

b

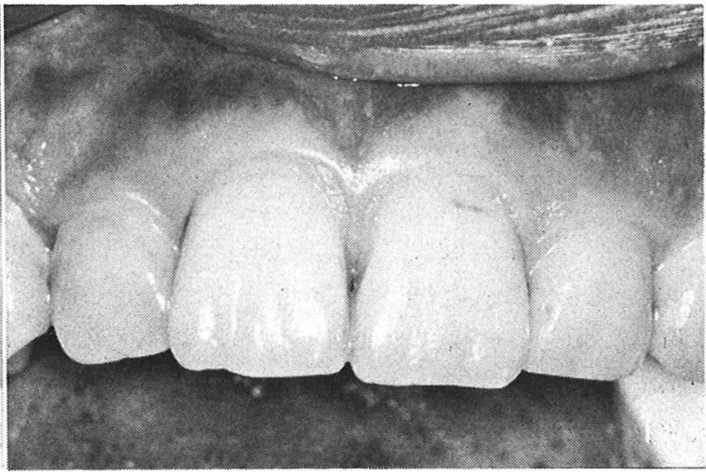

d

図 $5(a \sim d)$ 規格写真の 1 例, a, b, c, d 恃同一被検者について撮影された 8 枚より 1 枚おきに抜き出して例示したものである。 
表 1 各被検者における測定值の変動（上顎 左右中切歯の面積) : 単位は $5 \mathrm{~mm}$ 平 方の亦す目の数。

\begin{tabular}{|c|c|c|c|c|c|}
\hline Subject & Minimum & Maximum & Mean & S.D. & C.V. $(\%)$ \\
\hline$\lfloor 1$ & 1000 & 1041 & 1026.9 & 13.8 & 1.3 \\
\hline 1 & 963 & 1057 & 1023.6 & 27.6 & 2.7 \\
\hline \multirow[t]{2}{*}{2} & 1052 & 1092 & 1068.3 & 11.1 & 1.0 \\
\hline & 1046 & 1133 & 1101.9 & 24.8 & 2.3 \\
\hline 3 & 935 & 1009 & 980.0 & 27.2 & 2.8 \\
\hline 1 & 957 & 1002 & 983.0 & 15.9 & 1.6 \\
\hline 4 & 1161 & 1395 & 1254.6 & 83.9 & 6.7 \\
\hline 1 & 1344 & 1433 & 1383.0 & 33.3 & 2.4 \\
\hline \multirow[t]{2}{*}{5} & 1015 & 1232 & 1118.4 & 71.9 & 6.4 \\
\hline & 1011 & 1245 & 1135.2 & 79.2 & 7.0 \\
\hline 6 & 957 & 992 & 968.4 & 12.7 & 1.3 \\
\hline 1 & 1000 & 1052 & 1021.0 & 17.2 & 1.7 \\
\hline 7 & 800 & 1001 & 930.6 & 77.7 & 8.3 \\
\hline 1 & 922 & 1041 & 1008.0 & 44.5 & 4.4 \\
\hline 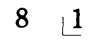 & 875 & 929 & 903.8 & 20.8 & 2.3 \\
\hline 1 & 887 & 900 & 891.2 & 4.7 & 0.5 \\
\hline $9 \quad 1$ & 913 & 956 & 935.4 & 15.9 & 1.7 \\
\hline 9 & 997 & 1050 & 1013.8 & 19.7 & 1.9 \\
\hline \multirow[t]{2}{*}{10} & 949 & 1056 & 977.6 & 39.8 & 4.1 \\
\hline & 976 & 1061 & 1006.8 & 32.2 & 3.2 \\
\hline \multirow[t]{2}{*}{11} & 991 & 1107 & 1057.6 & 40.9 & 3.9 \\
\hline & 1066 & 1164 & 1095.8 & 3.9 & 3.2 \\
\hline \multirow[t]{2}{*}{12} & 834 & 921 & 882.8 & 29.7 & 3.4 \\
\hline & 874 & 971 & 914.0 & 34.4 & 3.8 \\
\hline Mean & - & - & - & - & 3.2 \\
\hline
\end{tabular}

S.D. = standard deviation

C.V. = coefficient of variation

1,$2 ;$ faculty, $3-12 ;$ student.

たる。

各被検者における，上顎左右中切歯の面積の最小値， 最大值, 平均值, 標準偏差および变異係数を表 1 に示 す。標準偏差を平均値で割って得た変異係数 (百分率) は, $0.5 \%$ から $8.3 \%$ の間に分布し, 平均 $3.2 \%$ であっ た。

上顎左右中切歯に設定した線分 $\mathrm{OX}_{1}, \mathrm{OX}_{2}, \mathrm{Y}_{1} \mathrm{Y}_{1}^{\prime}$, $\mathrm{Y}_{2} \mathrm{Y}_{2}^{\prime}$ の距離を, 各被検者について測定した值の最小值, 最大值, 平均值, 標準偏差および変異係数を表 2 に示 す。 $\mathrm{OX}_{1}, \mathrm{OX}_{2}, \mathrm{Y}_{1} \mathrm{Y}_{1}^{\prime}, \mathrm{Y}_{2} \mathrm{Y}_{2}^{\prime}$ に関する変異係数の平均は, それぞれ $1.62 \%, 1.67 \%, 1.54 \%$ および $1.56 \%$ であっ た。
表 2 各被検者における測定值の変動（上顎左右中 切歯に設定された定点間の距離):単位は $\mathrm{mm}$ 。

\begin{tabular}{|c|c|c|c|c|c|}
\hline Subject & \multicolumn{2}{|c|}{ Minimum Maximum } & \multirow{2}{*}{$\begin{array}{l}\text { Mean } \\
141.5\end{array}$} & \multirow{2}{*}{$-\frac{\text { S.D. }}{2.45}$} & \multirow{2}{*}{$\frac{\text { C.V. }(\%)}{1.7}$} \\
\hline $1\left\lfloor 1 \quad O X_{2}\right.$ & 137.5 & 146 & & & \\
\hline $\mathrm{Y}_{2} \mathrm{Y}_{2}^{\prime}$ & 205 & 210 & 208.1 & 1.81 & 0.87 \\
\hline $1 \mid \mathrm{OX}_{1}$ & 130.5 & 138 & 134.4 & 2.77 & 2.1 \\
\hline$Y_{1} Y_{1}^{\prime}$ & 205 & 211 & 208.5 & 2.25 & 1.1 \\
\hline $2\left\lfloor 1 O \mathrm{OX}_{2}\right.$ & 154 & 162 & 157.6 & 2.51 & 1.6 \\
\hline$Y_{2} Y_{2}^{\prime}$ & 191 & 196 & 193.6 & 1.49 & 0.77 \\
\hline $1 \mathrm{OX}$ & 163 & 167.5 & 165.4 & 1.49 & 0.90 \\
\hline$Y_{1} Y_{1}^{\prime}$ & 195 & 230 & 201.9 & 10.9 & 5.4 \\
\hline $3\left\lfloor 1 O \mathrm{X}_{2}\right.$ & 151 & 156 & 154.4 & 1.85 & 1.2 \\
\hline $\mathrm{Y}_{2} \mathrm{Y}_{2}^{\prime}$ & 180.5 & 186 & 184.0 & 2.17 & 1.2 \\
\hline 1$] \mathrm{OX}_{1}$ & 152 & 157 & 154.0 & 1.70 & 1.1 \\
\hline $\mathrm{Y}_{1} \mathrm{Y}_{1}^{\prime}$ & 180.5 & 183.5 & 182.2 & 1.03 & 0.57 \\
\hline $41 O_{2}$ & 157 & 162.5 & 160.5 & 2.77 & 1.7 \\
\hline$Y_{2} Y_{2}^{\prime}$ & 212 & 224 & 218.3 & 4.49 & 2.1 \\
\hline $1 / X_{1}$ & 177 & 184 & 180.2 & 2.48 & 1.4 \\
\hline$Y_{1} Y_{1}^{\prime}$ & 212 & 218 & 214.0 & 2.28 & 1.1 \\
\hline $5 \mid 1 O \mathrm{OX}_{2}$ & 155.5 & 160 & 157.5 & 1.48 & 0.94 \\
\hline $\mathrm{Y}_{2} \mathrm{Y}_{2}^{\prime}$ & 201.5 & 208.5 & 205.5 & 2.35 & 1.1 \\
\hline $1 / O X_{1}$ & 145 & 163.5 & 154.7 & 6.54 & 4.2 \\
\hline$Y_{1} Y_{1}^{\prime}$ & 207 & 213 & 210 & 2.19 & 1.0 \\
\hline $6: 1 O^{2} X_{2}$ & 144 & 153 & 148.4 & 3.44 & 2.3 \\
\hline $\mathrm{Y}_{2} \mathrm{Y}_{2}^{\prime}$ & 160 & 167 & 164.7 & 2.60 & 1.6 \\
\hline $1 / X_{1}$ & 130.5 & 145 & 139.7 & 5.86 & 4.2 \\
\hline$Y_{1} Y_{1}^{\prime}$ & 184.5 & 187 & 185.6 & 0.86 & 0.46 \\
\hline $7 \mid 1 \quad O X_{2}$ & 147 & 153 & 149.9 & 2.42 & 1.6 \\
\hline $\mathrm{Y}_{2} \mathrm{Y}_{2}^{\prime}$ & 183.5 & 188.5 & 185.8 & 3.01 & 1.6 \\
\hline $1 / \mathrm{OX}_{1}$ & 152 & 156 & 154.6 & 1.50 & 0.97 \\
\hline$Y_{1} Y_{1}^{\prime}$ & 182.5 & 191.5 & 187.7 & 3.59 & 1.9 \\
\hline $8 \mid 1 \quad O X_{2}$ & 148 & 152 & 150.1 & 1.50 & 1.0 \\
\hline $\mathrm{Y}_{2} \mathrm{Y}_{2}^{\prime}$ & 181 & 185 & 182 & 1.37 & 0.75 \\
\hline $1 \mid O X_{1}$ & 146 & 149 & 147.8 & 1.17 & 0.79 \\
\hline$Y_{1} Y_{1}^{\prime}$ & 178 & 182 & 180 & 1.50 & 0.83 \\
\hline $9\left\lfloor 1 O \mathrm{X}_{2}\right.$ & 151 & 156.5 & 153.4 & 2.27 & 1.5 \\
\hline $\mathrm{Y}_{2} \mathrm{Y}_{2}^{\prime}$ & 174 & 183 & 179 & 3.14 & 1.8 \\
\hline $1 \mid \mathrm{OX}_{1}$ & 157.5 & $160^{\circ}$ & 158.5 & 0.89 & 0.56 \\
\hline$Y_{1} Y_{1}^{\prime}$ & 174 & 182 & 178.7 & 2.62 & 1.5 \\
\hline $10110 X_{2}$ & 150 & 158.5 & 154.3 & 3.37 & 2.2 \\
\hline $\mathrm{Y}_{2} \mathrm{Y}_{2}^{\prime}$ & 172 & 186 & 177.2 & 5.15 & 2.9 \\
\hline $1 / O X_{1}$ & 151 & 159 & 154.8 & 2.99 & 1.9 \\
\hline$Y_{1} Y_{1}^{\prime}$ & 173 & 185.5 & 177.8 & 4.78 & 2.7 \\
\hline $11\left\lfloor 1 \quad O X_{2}\right.$ & 154.5 & 160 & 157.2 & 2.06 & 1.3 \\
\hline $\mathrm{Y}_{2} \mathrm{Y}_{2}^{\prime}$ & 191.5 & 198 & 195.8 & 2.48 & 1.3 \\
\hline $1 / \mathrm{OX}_{1}$ & 164 & 167 & 165 & 1.10 & 0.67 \\
\hline$Y_{1} Y_{1}^{\prime}$ & 178 & 181 & 179.9 & 1.11 & 0.62 \\
\hline $12\left\lfloor\mathrm{OXX}_{2}\right.$ & 145 & 158.5 & 151.8 & 4.61 & 3.0 \\
\hline $\mathrm{Y}_{2} \mathrm{Y}_{2}^{\prime}$ & 160 & 169 & 164.2 & 3.31 & 2.0 \\
\hline $1 \mid \mathrm{OX}_{1}$ & 155.5 & 158.5 & 157.2 & 1.08 & 0.69 \\
\hline $\mathrm{Y}_{1} \mathrm{Y}_{1}^{\prime}$ & 174 & 181 & 176.5 & 2.37 & 1.3 \\
\hline Mean & & & & & \\
\hline $1 \mathrm{OX}_{2}$ & & & & & 1.67 \\
\hline $\mathrm{Y}_{2} \mathrm{Y}_{2}^{\prime}$ & & & & - & 1.56 \\
\hline $1 / \mathrm{OX}_{1}$ & & & & & 1.62 \\
\hline $\mathrm{Y}_{1} \mathrm{Y}_{1}^{\prime}$ & & & & $\ldots$ & 1.54 \\
\hline
\end{tabular}

S.D. = standard deviation. C.V. = coefficient of variation 1,2 ; faculty, $3-12$; student. 


\section{考察}

撮影された写真が規格写真であるためには，それがカ ラー写真であった場合では, 色調, コントラストなども 重要であるが, 本稿では, 形態の再現ということに論点 をしぼった。

規格写真の撮影には，被写体とカメラとの位置関係が 常に一定であることが必要である。

従来の規格写真撮影装置は, その固定源の求め方によ り大きく 3 種に分類される。すなわち, (1) 口腔外の顔面 頭部に固定源を求める方法, (2) 口腔内の歯列にそれを求 める方法, および, (3) 口腔内, 口腔外の両者に固定源を 求める方法である。(1) の方法としては，今川らの方法 がある。これは，眼科用頤固定装置を用いて顔がいつも 一定の位置に固定されるようにし, それに対向するカメ ラにより常に一定の位置から撮影するようになってい る。(2) の方法としては, 川島の方法, AL-JAZRAWI の 方法がある。川島は, 口腔内に装着できる特殊なシーネ を作製し，それから出した 3 つの固定点とカメラより出 した 3 つの固定点がそれぞれ一致するようにカメラの位 置, 方向を決めて, 写真に規格性を与えた。AL-JAZRA WI は, 金属とアクリリックレジンおよびシリコンベー スからなるバイトブロックを作製した。そして，しっか り咬合されたバイトブロックから口腔外に出ている金属 棒上にカメラを固定し，規格写真の撮影をおこなった。 (3)の方法として野口は, サルにおいて歯垢量を測定する 際，独自の規格撮影装置を工夫し使用した。これは，サ ルの頭部を固定する装置と，それに連結したレール上を 移動できるカメラ，および各サルについて作製された口 腔内シーネから成る。これらの使用により, サルの口腔 は常に一定の位置にくるようになり, 結果は満足すべき ものであったと述べている。

今回，著者らの作製した装置は，特別な固定装置を用 いずに，被写体とカメラとの位置関係を確保しようとし たものである。そのため, 使用上の煩雑さは大いに改善 されたと思われる。使用したカメラは固定焦点である。 したがって，視野上の 1 点から見た場合，カメラは，焦 点距離を半径とした球面上の 1 点にあることになる。ま た，ある程度の焦点深度が存在するので，ピントを合わ せても，被写体とカメラとの間の距離は一定とならな W。

そこで, カメラより 3 本の腕を出し, 一定距離を確保 すると同時に，1平面を規定し，カメラと被写体との関
係を球面から平面へと変えた。次に，フォーカシングス クリーン上に定点を定め, それが被写体の 1 定点と一致 するよらにした。この操作により，カメラは，1平面上 の決められた 1 視野に固定されることになる。今回, 著 者らはこの操作を, フォーカシングスクリーン上のスプ リットマイクロプリズムの外側の円弧が $1 \mid 1$ の切縁を結 んだ線に中央部分で接するように規定した（図 3)。しか し，それにかえて，撮影したい対象が視野の中央にくる ように適宜決めることも可能である。

本装置の規格性の検討には，くりかえし撮影されたス ライドを 10 倍で拡大投影し，トレース後，同一部分の 面積を測定比較することにより，また，定点間の距離を 測定比較することにより抽なった。したがって結果 は，一連の操作上おこりうるすべての䛊差を含んでい る。面積のほか, 距離を測定した理由は，ある特定方向 における“ゆがみ”の存在を見るためであった。

規格装置に操作上全くミスが入らなければ，測定値は 一定の值をとるはずである。しかし，そのようなことは 実際上考えにくい。一般にある種の測定操作をくりかえ しておこなった場合の結果は，正規分布に従うと考えら れる。

したがって，再現性，規格性がよいということは結果 のばらつきが少ない，つまり，その標準偏差（分散）が 小さいということである。そのため，著者らは，変異係 数により，結果の検討をおこなった。

規格装置の性能としては，誰が，いつ，どこで使用し ても変動が少ないということが重要である。そのため, 検者は 2 名とし, 被検者もバイトブロックを使用した 2 名と中心咬合位で咬合させた 10 名の計 12 名を用いた が，結果に特に大きな差は認められないように思われ る。

また，規格装置にどのような性能を求めるかは，その 装置を使用する目的にもよると考えられる。非常に微小 な変化をとらえるためには，高い精度が求められること になる。結果から面積のバラッキを見ると，変異係数で 平均 $3.2 \%$ であった。また，距離では，各方向とも特 に大きな差はなく，変異係数で $1.6 \%$ 程度であった。 これらは，距離で 10 倍，すなわち面積では 100 倍に拡 大した場合での結果であるから，本装置は特に高い信頼 度を求めないなら，十分な規格性を有していると思われ る。

前述したように，本装置はカメラの位置決定に，視野 中央部の 1 定点を利用した。そのため, 規格装置として の操作性は向上したが，視野中央部の 1 定点としたた 
め, 光軸上におけるカメラの回転という要素の規制とい う点で弱い結果となった。この欠点を補うためには，視 野周辺部の 1 定点を新たに加え, 2 点で規制するのがよ いと思われるが，このこともあわせ，さらに，カメラ， 装置に改良を加えたいと考える。

\section{総括および結論}

簡単な操作で, より精度の高い規格写真を撮影するた めの装置を試作し，その性能を調べた。その結果，くり かえして撮影されたスライドを方眼紙上に 10 倍で拡大 投影, トレース後, 面積を測定した場合, 平均 $3.2 \%$ の 変異係数を示し, また, 定点間の距離を測定した場合で は, 平均 $1.6 \%$ の変異係数を示した。したがって, 本装 置は, 特に高い信頼度を求めないなら，十分な規格性を 有していると思われた。

\section{文献}

1）今川与曹, 石川 純, 中村治郎, 川崎 仁, 松江
一郎, 鈴木文雄, 加藤 笣, 長谷川紘司 : 口腔内 写真規格撮影法, 口科誌, $15: 190,1966$.

2）中村治郎, 原 耕二, 加藤 熙, 長谷川紘司, 松 丸健三郎：歯周疾患の治療効果に関する生物学的 研究 歯周疾患に対する食塩及びブラッシングの 影響について, 日保歯誌, 9:328-347, 1967.

3）川島泰三 : 天然歯および歯冠補綴物の歯肉辺縁付 近における歯垢沈着について, 補緅誌, $22: 432-$ 459, 1978.

4) ADNAN AL-JAZRAWI : The Effect of a Mouthwash Containing Oleylamine-Hydrofluoride on Supragingival Calculus Formation, 1st ed., Juris Druck + Verlag Zürich, 1973, 17-18.

5）野口俊英 : デキストラナーゼの歯垢沈着に及ぼす 影響についてーアカゲザルにおける観察一, 口病 誌, $39 ：$ 787-799, 1972. 